Research Paper

\title{
Malignant ascites enhances migratory and invasive properties of ovarian cancer cells with membrane bound IL-6R in vitro
}

\author{
Soochi Kim ${ }^{1,2}$, HyeRan Gwak2,3, Hee Seung Kim ${ }^{2,4}$, Boyun Kim²,5, Danny N. \\ Dhanasekaran', Yong Sang Song ${ }^{1,2,3,4}$ \\ ${ }^{1}$ Interdisciplinary Program in Cancer Biology, College of Medicine, Seoul National University, Seoul, Republic of Korea \\ ${ }^{2}$ Cancer Research Institute, Seoul National University, Seoul, Republic of Korea \\ ${ }^{3}$ Biomodulation, Department of Agricultural Biotechnology, Seoul National University, Seoul, Republic of Korea \\ ${ }^{4}$ Department of Obstetrics and Gynecology, Seoul National University, Seoul, Republic of Korea \\ ${ }^{5}$ Nano System Institute, Seoul National University, Seoul, Korea \\ ${ }^{6}$ Stephenson Cancer Center, University of Oklahoma Health Sciences Center, USA \\ Correspondence to: Yong Sang Song, email: yssong@snu.ac.kr
}

Keywords: ascites, migration, invasion, IL-6R, ovarian cancer

Received: April 18, $2016 \quad$ Accepted: October 11, 2016

Published: November 4, 2016

\section{ABSTRACT}

Transcoelomic route is the most common and the earliest route of metastasis, causing the ascites formation in advanced epithelial ovarian cancer (EOC). We demonstrated that interleukin 6 (IL-6) is enriched in the malignant ascites from patients with ovarian cancer, which enhanced invasive properties of EOC cells. Interestingly, the expression of IL-6R on cell membrane of EOC cells correlated with ascites-induced invasion. Selective knockdown of IL-6R or inhibition with IL-6 neutralizing antibody, suppressed the stimulatory effects of ascites on EOC invasion. Moreover, the ascites treatment induced the phosphorylation of JAK2-STAT3 and use of selective inhibitors of JAK2 and STAT3, blocked the expression of epithelial-mesenchymal transition related proteins in parallel with the suppression of EOC invasion. Thus, IL-6/IL-6R mediated JAK2-STAT3 signaling pathway could be a promising therapeutic target for anticancer therapy in ovarian cancer patients with ascites.

\section{INTRODUCTION}

Epithelial ovarian cancer (EOC) is the most lethal gynecological malignancy due to the frequent relapse and chemoresistance. Asymptomatic nature of the disease, largely contributes to the diagnosis of patients in advanced stage III/IV, causing a greater than $60 \%$ mortality rate within five years [1]. In contrast to other solid tumor, the metastatic pattern of ovarian cancer is unique. The most common and earliest route of metastasis is transcoelomic, which frequently causes the accumulation of fluid in the peritoneal cavity, called ascites [2]. Clinically, the presence of ascites is significantly associated with a decreased quality of life and a poor prognosis [3, 4].

In general, ascites formation provides a favorable environment for tumor cells. The role of ascites in ovarian cancer progression is diverse, including promotion of proliferation, spheroid formation, attenuation of TRAIL- induced apoptosis and enhanced invasive behavior [57]. Ascites are composed of both cellular and acellular components, each of which has a distinctive but cumulative role in disease progression. The concentration of bio-active molecules present in ascites varies between patients, according to their disease stage, grade and histological subtypes [8, 9]. Variety of soluble factors including inflammatory cytokines has been demonstrated to individually affect EOC progression through different mechanisms. Of those, high level of IL-6 in the serum and ascites of the cancer patients has been shown to be associated with worse clinical outcomes $[10,11]$. The signaling pathway downstream of IL-6, especially JAKSTAT3 pathway is aberrantly activated and is associated with the cancer progression, though this pathway is an essential component of normal development and homeostasis [12].

Ovarian cancer cells in malignant ascites have also been characterized by epithelial mesenchymal transition 
(EMT), supporting the idea that ascites contains factors mediating the EMT pathway and metastasis [13]. Although previous studies have demonstrated the stimulatory role of ascites in migration and invasion of EOC cells, its exact mechanism has not been determined. Herein we report that human ovarian cancer patient derived ascites comprises proinflammatory tumor microenvironment (TME), of which elevated levels of IL-6 increased EOC cell invasion through JAK2-STAT3 signaling in parallel with increased expression of EMT related genes. Furthermore, our data indicated that, the expression of IL-6R on cell membrane of EOC cells is correlated with ascites induced invasion in vitro.

\section{RESULTS}

\section{Ascites promotes migration and invasion of EOC cells}

To assess the role of ascites in the migration and invasion of ovarian cancer cells, three ascites were randomly selected from women with advanced serous ovarian carcinoma, which is the most commonly encountered ovarian cancer subtype in clinical intervention. SKOV-3 cancer cell line, the most commonly used cellular models of ovarian cancer were used to confirm the effect of ascites on EOC cell migration and invasion. Using in vitro migration (wound healing) and invasion (Matrigel-coated transwell) assay, we found all three ascites from ovarian cancer patients increase migration and invasion in SKOV-3 (Figure 1A and 1B). However, this phenomenon was only confined to SKOV-3 ovarian cancer cells, and did not occur in normal immortalized ovarian surface epithelial cells (IOSE380) (Figure 1C). It has been established that cells with mesenchymal phenotype are endowed with enhanced migration and invasive capabilities [14] and EMT-dependent invasion and metastasis programs are strongly responsive to microenvironment changes [15, 16]. Therefore, we determined the effect of ascites on the expression of EMT related proteins. We found all three ascites from ovarian cancer patients reduced the expression of an epithelial marker (E-cadherin), and increased the expression of mesenchymal markers (Snail and Vimentin) (Figure 1D and 1E) and these changes were statistically significant (Supplementary Figure S1A and $\mathrm{S} 1 \mathrm{~B})$. Although, the expression of $\mathrm{N}$-cadherin is induced in the first $30 \mathrm{~min}$ of ascites treatment and decreased thereafter, ascites treatment decreased overall E-/Ncadherin ratio (Supplementary Figure S1C and S1D).

\section{High levels of pro-inflammatory cytokines in malignant ascites from patients with ovarian cancer}

Ascites constitutes a dynamic reservoir of soluble factors, which individually and in a combined fashion may affect tumor cells behavior [17]. To determine the cytokine(s) in ascites that are associated with EMTdependent invasion of SKOV-3 cells, we evaluated a panel of cytokines using a cytokine array. Using two peritoneal fluids as benign control (Table 1, description of patients), the presence of pro-inflammatory cytokines in ovarian cancer patient derived ascites were compared. From relative comparison, we found IL-6 expression only in ovarian cancer patient derived ascites (Figure 2A and 2B). Then we applied enzyme-linked immunosorbent assay (ELISA), to measure the IL-6 levels. IL-6 was present at high levels ( $>3 \mathrm{ng} / \mathrm{ml}$ ) in all three tested ascites (Figure 2D).

\section{IL-6 in ascites increase migration and invasion via JAK2-STAT3 signaling}

To investigate whether IL-6 enriched in ascites increased SKOV-3 cell migration and invasion, we applied neutralization approach. Ascites were pre-treated with neutralizing IL-6 antibody for $6 \mathrm{hr}$. This process suppressed the enhanced migration and invasion in SKOV-3 cells (Figure 3A and 3B). Importantly, we also found that neutralization of IL-6 in ascites suppressed the effect of ascites on the expression of EMT related proteins (Figure 3C and Supplementary Figure S3A). Moreover, ascites treatment did not affect IL-6 autocrine expression in SKOV-3 cells (Supplementary Figure S2A and S2B). Perturbed JAK2-STAT3 signaling pathway is implicated in a range of cancers and influences various cellular processes including invasion $[18,19]$. To investigate this point, we first examined the effect of ascites on tyrosine phosphorylation of JAK2 and STAT3 in SKOV-3 cells. As expected, we found that ascites treatment induced both JAK2 and STAT3 phosphorylation on Tyr1007 and Tyr705, respectively. STAT3 was rapidly phosphorylated upon ascites treatment, reaching the highest level at the 30 min time point, and declined rapidly (Figure $3 \mathrm{D}$ and Supplementary Figure S3B). However, this phenomenon was only confined to ovarian cancer cells, SKOV-3 cells, and did not occur in normal IOSE380 cells (Figure 3E and Supplementary Figure S3C). Moreover, pre-treatment with neutralizing IL-6 antibody as above, suppressed the ascites induced JAK2 and STAT3 phosphorylation (Figure 3F and Supplementary Figure S3D). To further validate the necessity of JAK2-STAT3 in ascites enhanced invasion in SKOV-3 cells, we used WP1066 (an inhibitor of JAK2 and STAT3, $2 \mu \mathrm{M}$ ) and TG101348 (an inhibitor for JAK2, $1 \mu \mathrm{M}$ ) to expectably suppress the JAK2 and STAT3 signaling activity. Both inhibitors significantly suppressed the enhanced migration and invasion in SKOV3 cells (Figure 4A and 4B). Importantly, co-treatment with these inhibitors markedly reversed the acquisition of mesenchymal cell markers upon ascites treatment (Figure 4C and Supplementary Figure S4A) and also reversed the ascites induced JAK2 and STAT3 phosphorylation (Figure 
(A)
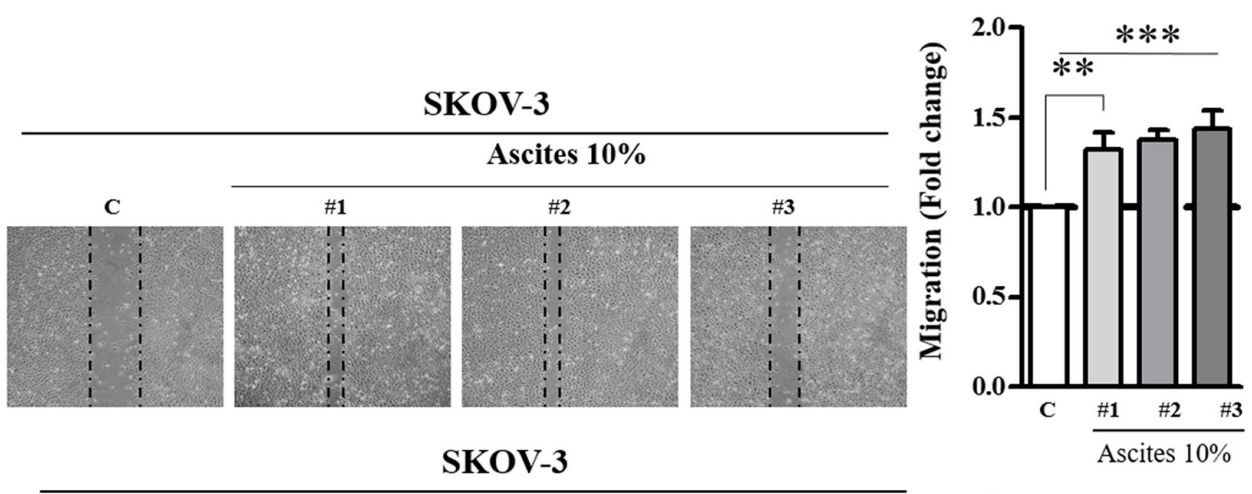

(B)
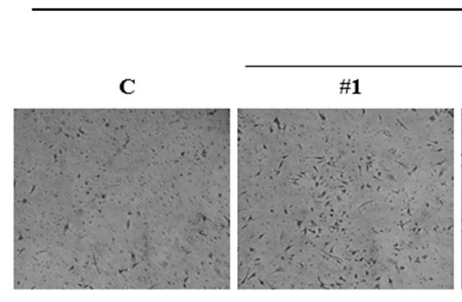

Ascites 10\%

(C) C
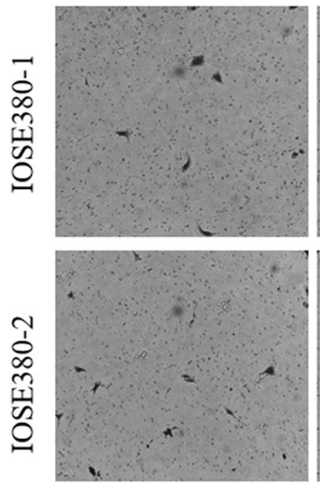

Ascites \#3
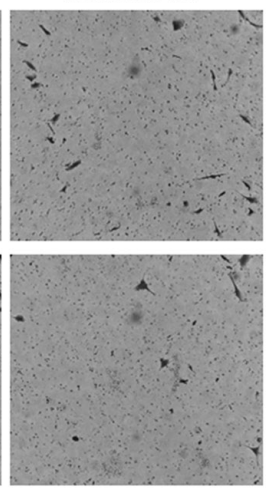

SKOV-3

(E)

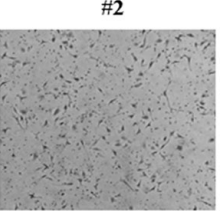

\#3

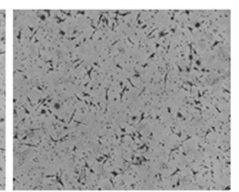

SKOV-3

(D)
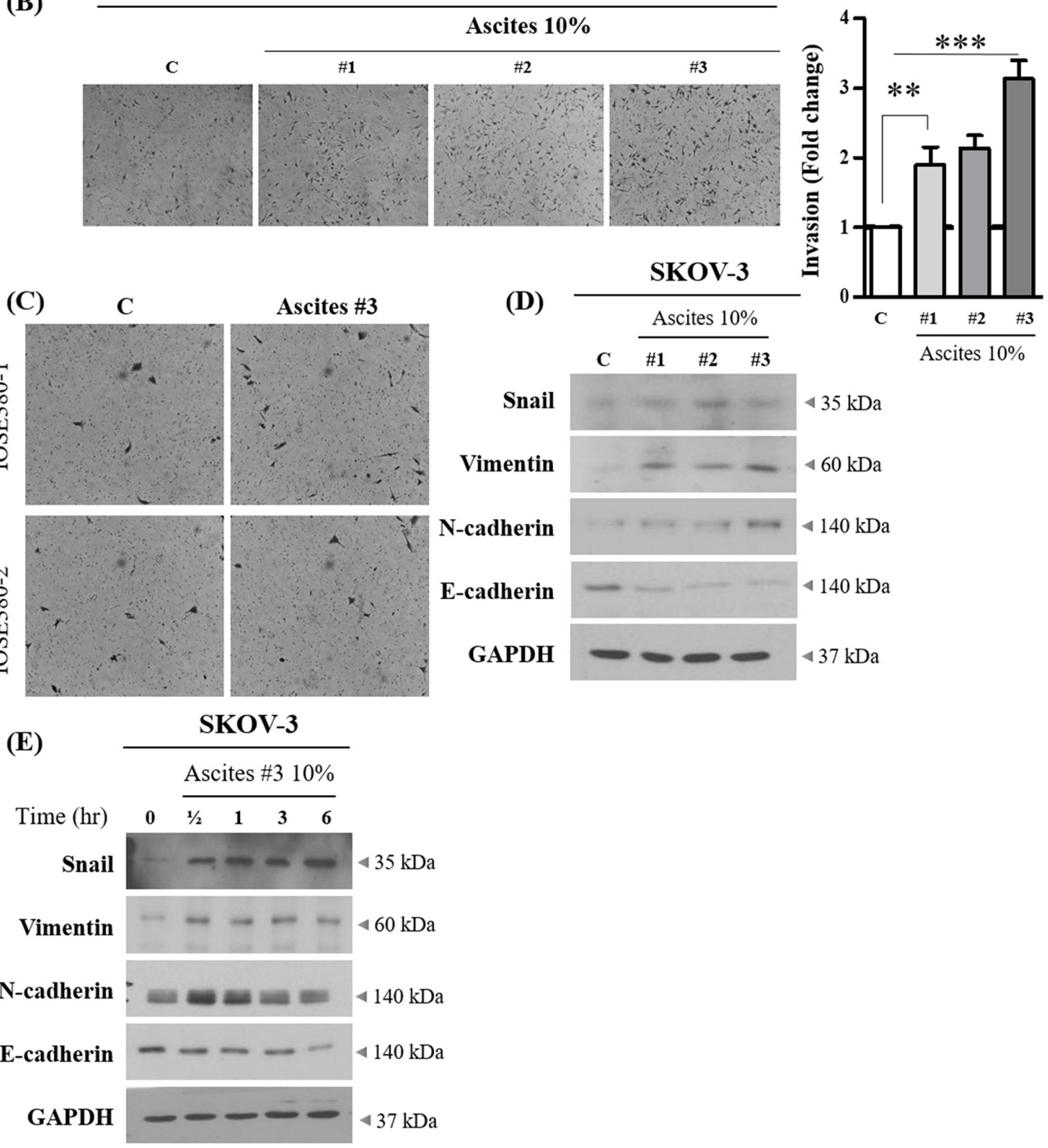

Figure 1: Effect of ovarian cancer patient derived ascites on SKOV-3 cell migration and invasion. A. SKOV-3 cancer cells were treated with or without $10 \%$ ascites. After $24 \mathrm{hr}$, wound healing ability was verified by measuring wound closed area under a light microscope (magnification x 40). B. SKOV-3 cancer cells were seeded into the upper chamber of Matrigel-coated membrane in transwells. Cell invasion were induced with or without $10 \%$ ascites. After $24 \mathrm{hr}$, invaded cells at the bottom of the transwell were stained with $0.5 \%$ crystal violet and were counted under a light microscope (magnification x 200). C. IOSE380 cells were seeded into the upper chamber of Matrigel-coated membrane in transwells. Cell invasion were induced and counted as above. D. SKOV-3 cancer cells were treated with or without $10 \%$ ascites. After $24 \mathrm{hr}$, the expression levels of EMT molecular markers, Snail, Vimentin, N-cadherin and E-cadherin were examined by western blot. GAPDH was used as an internal control. E. SKOV-3 cancer cells were treated with or without $10 \%$ ascites for $0-6 \mathrm{hr}$. Total cell lysates were extracted and subjected to western blot as above. ** and *** represent $P<0.01$ and $P<0.001$, respectively. 
Table 1: Description of patients recruited in the study

\begin{tabular}{|c|c|c|c|c|c|c|c|c|}
\hline & $\begin{array}{l}\text { Patient } \\
\text { ID }\end{array}$ & Disease & Histopathology & STAGE & $\begin{array}{c}\text { Age at } \\
\text { diagnosis }\end{array}$ & Survival & $\begin{array}{l}\text { Survival } \\
\text { status }\end{array}$ & Tumor spread \\
\hline \multirow{3}{*}{ Cancer } & A\#1 & $\begin{array}{l}\text { Ovarian } \\
\text { cancer }\end{array}$ & Serous & IV & 79 & $\begin{array}{l}2 \text { years as } \\
\text { of } 09 / 06 / 16\end{array}$ & Alive & $\begin{array}{l}\text { Ovary, omentum, } \\
\text { pelvic lymph } \\
\text { node, colon } \\
\text { serosa, diaphragm }\end{array}$ \\
\hline & $\mathrm{A \# 2}$ & $\begin{array}{l}\text { Ovarian } \\
\text { cancer }\end{array}$ & Serous & IIIC & 72 & $\begin{array}{l}2 \text { years as } \\
\text { of } 27 / 06 / 16\end{array}$ & Alive & $\begin{array}{l}\text { Ovary omentum, } \\
\text { pelvic lymph } \\
\text { node, colon } \\
\text { serosa, appendix, } \\
\text { diaphragm }\end{array}$ \\
\hline & A\#3 & $\begin{array}{l}\text { Ovarian } \\
\text { cancer }\end{array}$ & Serous & IV & 68 & $\begin{array}{l}1 \text { year } 11 \\
\text { months as } \\
\text { of } 19 / 07 / 16\end{array}$ & NA & $\begin{array}{l}\text { Ovary, omentum, } \\
\text { bilateral sub- } \\
\text { diaphragmatic, } \\
\text { gallbladder, left } \\
\text { obturator }\end{array}$ \\
\hline \multirow[b]{2}{*}{ Benign } & B\#1 & $\begin{array}{l}\text { Para-tubal } \\
\text { cyst }\end{array}$ & NA & NA & 76 & & Alive & \\
\hline & $\mathrm{B} \# 2$ & $\begin{array}{l}\text { Ovarian } \\
\text { mucinous } \\
\text { cystadenoma }\end{array}$ & NA & NA & 55 & & Alive & \\
\hline
\end{tabular}

*NA: Not available

4D and Supplementary Figure S4B). These results suggest that ascites activate JAK2-STAT3 signaling pathway via IL-6 and increase SKOV-3 cell invasion.

\section{Ascites increase invasion only in ovarian cancer cells with IL-6R expression on cell membrane}

To determine whether ascites increase invasion in ovarian cancer cells in general or in a selective subset, additional ovarian cancer cell lines were tested. Four ovarian cancer cell lines including SKOV-3 were tested for expression of IL-6R at mRNA and protein levels. IL-6R were expressed in the 4 cell lines at both mRNA and protein levels (Figure 5A-5B and Supplementary Figure S5A-S5B). We found that ascites increase invasion only in PA-1 and SKOV-3 cells, but had no significant effect on OVCAR-3 and A2780 cell lines (Figure 5C). Interestingly, the effect of ascites treatment was not associated with endogenous IL-6 mRNA levels in ovarian cancer cell lines (Supplementary Figure S5C). Although the IL-6R protein is expressed in all four ovarian cancer cells tested, the expression of IL-6R on plasma membrane but not in cytosol of PA-1 and SKOV-3 cells correlate with ascites induced invasion (Figure 5D-5E and Supplementary Figure S5D). Finally, to link the IL6 $\mathrm{R}$ expression is critical for ascites mediated increased invasion in PA-1 and SKOV-3 cells, IL-6R was silenced and this process suppressed the ascites mediated enhanced invasion in these two cell lines (Figure 6A and 6B). These results demonstrate that IL- 6 in ascites increase invasion via IL-6R on cell membrane and thus increase invasive properties only in a selective subset of ovarian cancer cells.

\section{DISCUSSION}

Although the presence of ascites correlates with a poor prognosis in ovarian cancer patients, underlying molecular mechanism that lead to disease progression is poorly defined. Interestingly, the ascites presented in EOC patients constitute a dynamic reservoir of both protumorigenic and anti-tumorigenic factors [20]. Among several factors accumulated in ascites, we found that IL-6 is enriched in ascites and is responsible for increased invasion, suggesting that suppressing its downstream signals might decrease migration and invasion.

Here we screened 36 pro-inflammatory cytokines and found IL-6 expression only in ovarian cancer patient derived ascites but absent in peritoneal fluids from benign condition (Figure 2A). Early studies have also reported enrichment of pro-inflammatory cytokines such as IL-6, CXCL10, and CD54 in ascites and have a pro-metastatic role in ovarian cancer progression [7, 20-23]. IL-6 signals through binding to heterodimer of IL-6R and gp130 [24, $25]$ and is associated with the metastatic phenotype in a range of cancers [12], and Lane et al. reported that IL-6 
(A)

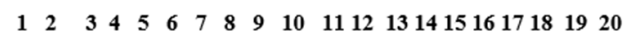

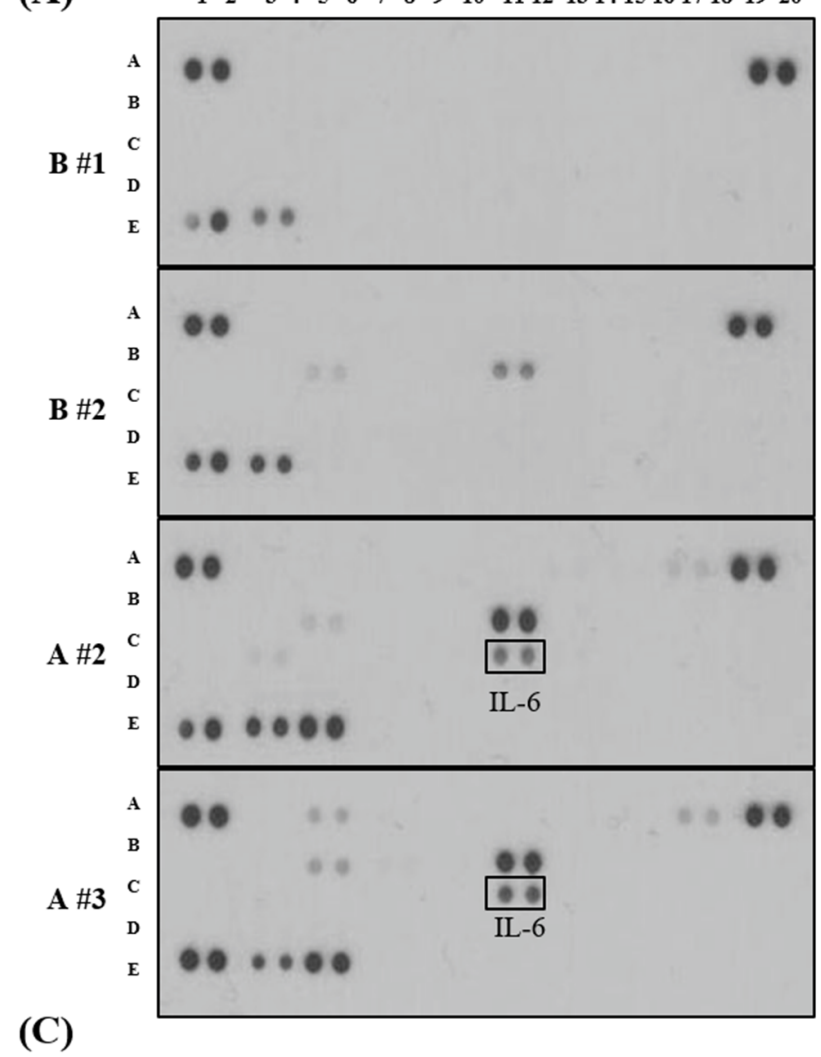

(C)

\begin{tabular}{|c|c|c|c|c|c|c|c|c|c|c|c|c|c|c|c|c|c|c|c|}
\hline- & $N$ & 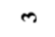 & T & $n$ & 6 & $r$ & $\infty$ & $a$ & $\varrho$ & $=$ & $\cong$ & 9 & $\Xi$ & $\stackrel{n}{-}$ & $\stackrel{0}{\simeq}$ & $\Xi$ & $\stackrel{\infty}{\sim}$ & $\stackrel{2}{二}$ & 구 \\
\hline RS & RS & $\begin{array}{c}\mathrm{CCL} \\
1\end{array}$ & $\begin{array}{c}\mathrm{CCL} \\
1\end{array}$ & $\begin{array}{c}\mathrm{CCL} \\
2\end{array}$ & $\begin{array}{c}\mathrm{CCL} \\
2\end{array}$ & $\begin{array}{l}\text { MIP. } \\
1 \alpha\end{array}$ & $\begin{array}{l}\text { MIP. } \\
1 \alpha\end{array}$ & $\begin{array}{c}\mathrm{CCL} \\
5\end{array}$ & $\underset{5}{\mathrm{CCL}}$ & $\underset{4}{\mathrm{CD} 15}$ & $\underset{4}{\mathrm{CD} 15}$ & $\begin{array}{c}\mathrm{C} 5 / \mathrm{C} \\
5 \mathrm{a}\end{array}$ & $\begin{array}{c}\mathrm{C} 5 / \mathrm{C} \\
5 \mathrm{a}\end{array}$ & $\begin{array}{c}\text { CXC } \\
\text { L1 }\end{array}$ & $\begin{array}{c}\text { CXC } \\
\text { L1 }\end{array}$ & $\begin{array}{l}\text { CXC } \\
\text { L10 }\end{array}$ & $\begin{array}{l}\text { CXC } \\
\text { L10 }\end{array}$ & RS & RS \\
\hline Blank & Blank & $\begin{array}{l}\text { CXC } \\
\text { L11 }\end{array}$ & $\begin{array}{l}\text { CXC } \\
\text { L11 }\end{array}$ & $\begin{array}{l}\text { CXC } \\
\text { L12 }\end{array}$ & $\begin{array}{l}\text { CXC } \\
\text { L12 }\end{array}$ & $\begin{array}{c}\text { G- } \\
\text { CSF }\end{array}$ & $\begin{array}{l}\text { G- } \\
\text { CSF }\end{array}$ & $\begin{array}{l}\text { GM- } \\
\text { CSF }\end{array}$ & $\begin{array}{l}\text { GM- } \\
\text { CSF }\end{array}$ & CD54 & CD54 & IFN- $\%$ & IFN- $\gamma$ & $\mathbb{I L}-1 \alpha$ & $\mathbb{I L}-1 \alpha$ & $\mathbb{L}-1 \beta$ & $\mathbb{L L}-1 \beta$ & Blank & Blank \\
\hline Blank & Blank & $\begin{array}{l}\text { IL- } \\
\text { 1ra }\end{array}$ & $\begin{array}{l}\text { II. } \\
\text { 1ra }\end{array}$ & IL -2 & IL -2 & IL-4 & IL-4 & IL-5 & IL-5 & IL-6 & ILL-6 & IL-8 & IL -8 & IIL-10 & IL-10 & $\begin{array}{c}\text { IL-12 } \\
\text { p70 }\end{array}$ & $\begin{array}{c}\text { IL-12 } \\
\text { p70 }\end{array}$ & Blank & Blank \\
\hline Blank & Blank & IL-13 & IL-13 & IL-16 & IL-16 & $\begin{array}{l}\text { IL- } \\
17 \mathrm{~A}\end{array}$ & $\begin{array}{l}\text { IL- } \\
17 \mathrm{~A}\end{array}$ & $\begin{array}{l}\text { IL- } \\
17 \mathrm{E}\end{array}$ & $\begin{array}{l}\text { IL- } \\
17 \mathrm{E}\end{array}$ & IL-18 & IL-18 & IL-21 & IL-21 & IL-27 & IL-27 & $\begin{array}{l}\text { IL- } \\
32 \alpha\end{array}$ & $\begin{array}{l}\text { II- } \\
32 \alpha\end{array}$ & Blank & Blank \\
\hline RS & RS & MIF & MIF & PAI- 1 & PAI-1 & $\begin{array}{c}\text { TNF- } \\
\alpha\end{array}$ & $\begin{array}{c}\text { TNF- } \\
\alpha\end{array}$ & $\begin{array}{l}\text { TRE } \\
\text { M-1 }\end{array}$ & $\begin{array}{l}\text { TRE } \\
\text { M-1 }\end{array}$ & Blank & Blank & Blank & Blank & Blank & Blank & Blank & Blank & $\mathrm{NegC}$ & $\mathrm{NegC}$ \\
\hline
\end{tabular}

(D)

\begin{tabular}{cc} 
Sample & IL-6 (ng/ml) \\
\hline A\#1 & 11.34 \\
A\#2 & 10.98 \\
A\#3 & 43.4 \\
\hline
\end{tabular}

(B)

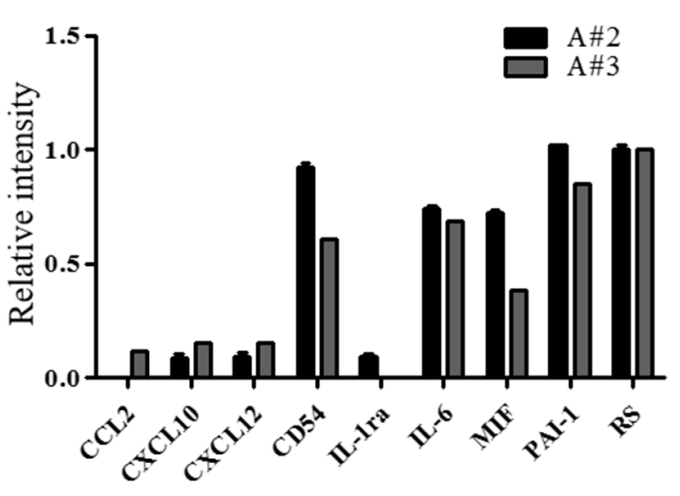


(A)

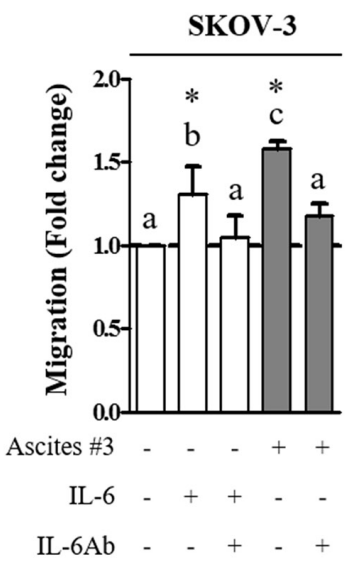

(C)

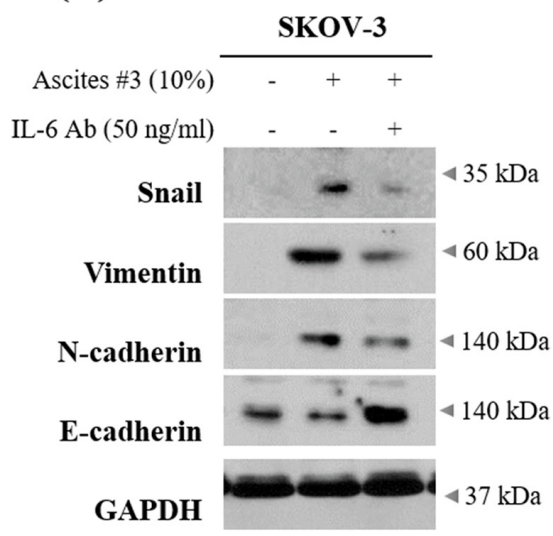

(E)

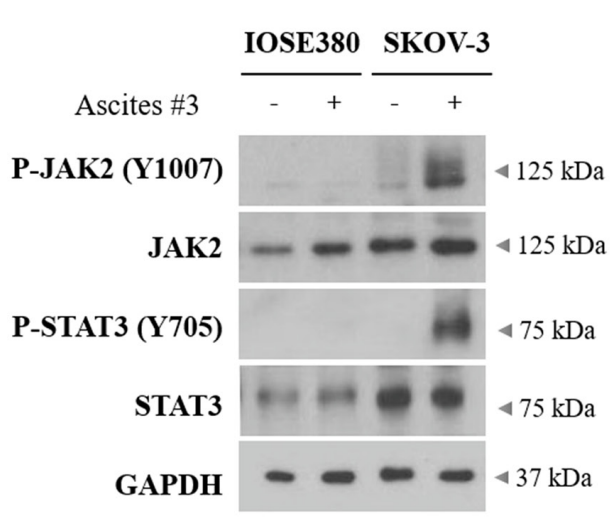

(B)

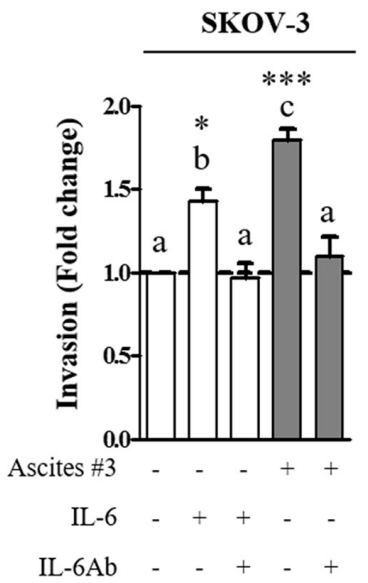

(D)

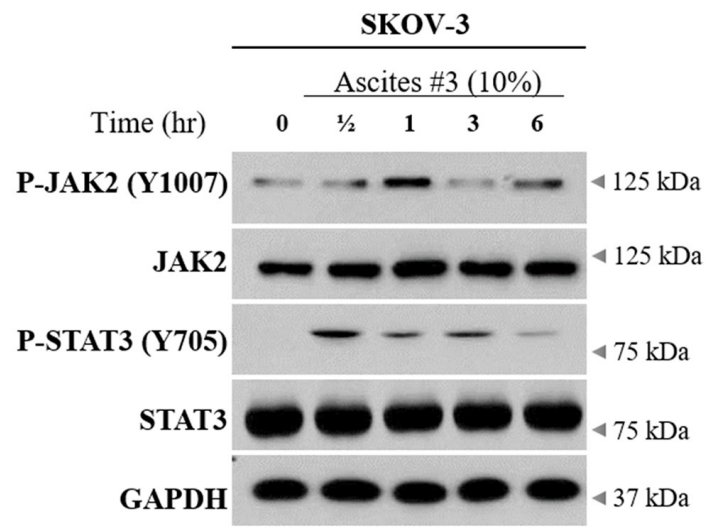

(F)

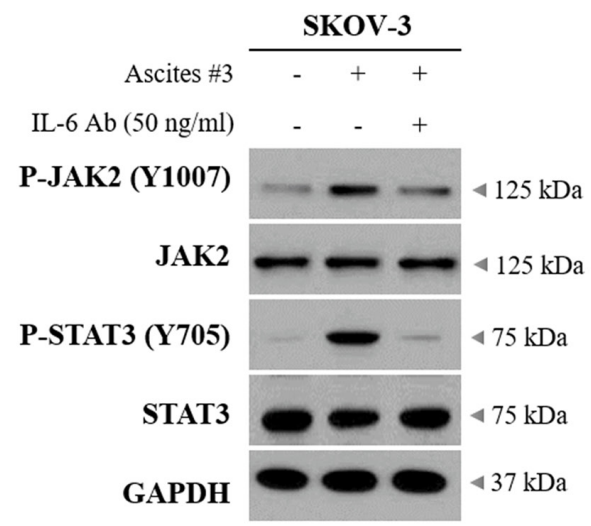

Figure 3: IL-6 in ovarian cancer patient derived ascites increase migration and invasion of SKOV-3 cells via JAK2STAT3 signaling. A. SKOV-3 cancer cells were treated with $10 \%$ ascites that were either pre-treated with or without $50 \mathrm{ng} / \mathrm{ml}$ of IL-6 antibody (IL-6 Ab) for $6 \mathrm{hr}$. Recombinant IL-6 (10 $\mathrm{ng} / \mathrm{ml})$ was used as a positive control. After $24 \mathrm{hr}$, wound healing ability was verified by measuring wound closed area under a light microscope (magnification $\mathrm{x} 40$ ). B. SKOV-3 cancer cells were seeded into the upper chamber of Matrigel-coated membrane in transwells. Cell invasion were induced by ascites as above. After $24 \mathrm{hr}$, invaded cells at the bottom of the transwell were stained with $0.5 \%$ crystal violet and counted under a light microscope (magnification x200). C. SKOV-3 cancer cells were treated with IL-6 Ab as above. After $24 \mathrm{hr}$, the expression of Snail, Vimentin, N-cadherin and E-cadherin were examined by western blot. GAPDH was used as an internal control. D. SKOV-3 cancer cells were treated with or without $10 \%$ ascites for $0-6 \mathrm{hr}$. The expression of p-JAK2 (Y1007), JAK2, p-STAT3 (Y705) and STAT3 were examined by western blot. GAPDH was used as an internal control. E. IOSE380 and SKOV-3 cells were treated with or without $10 \%$ ascites. After $0.5 \mathrm{hr}$, the expression of p-JAK2 (Y1007), JAK2, p-STAT3 (Y705) and STAT3 were examind by western blot. GAPDH was used as an internal control. F. SKOV-3 cancer cells were treated with IL-6 $\mathrm{Ab}$ as above. The expression of p-JAK2, JAK2, p-STAT3 and STAT3 were examined by western blot. GAPDH was used as an internal control. * and *** represent $P<0.05$ and $P<0.001$, respectively. 
(A)

\section{Ascites \#3 \\ WP1066}

TG101348

(B)

\section{Ascites \#3 \\ WP1066}

TG101348
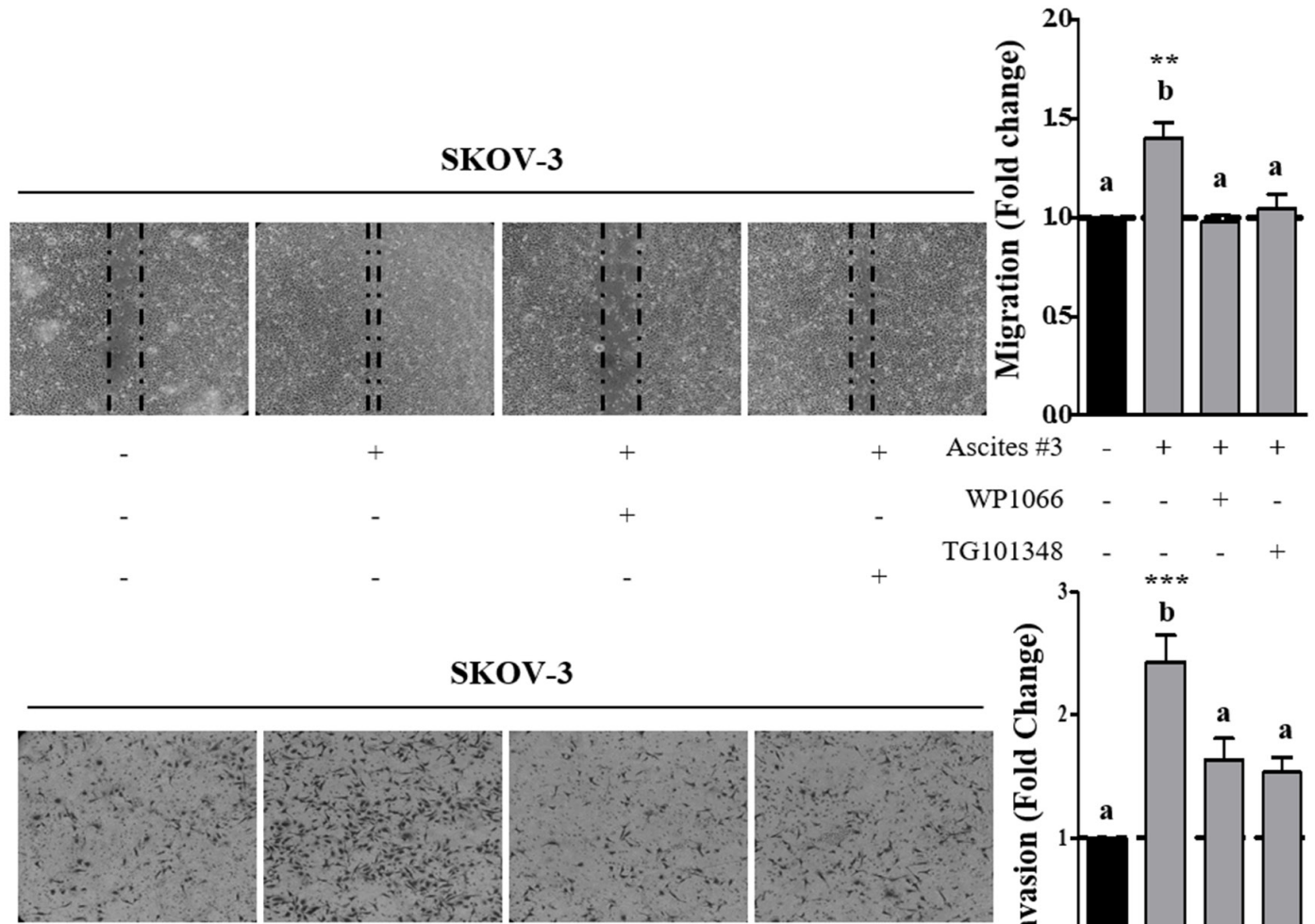

SKOV-3

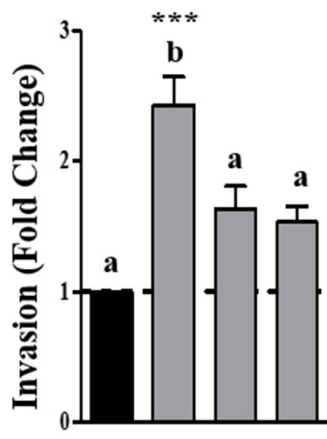

Ascites \#3

WP1066

$+\quad$ TG101348
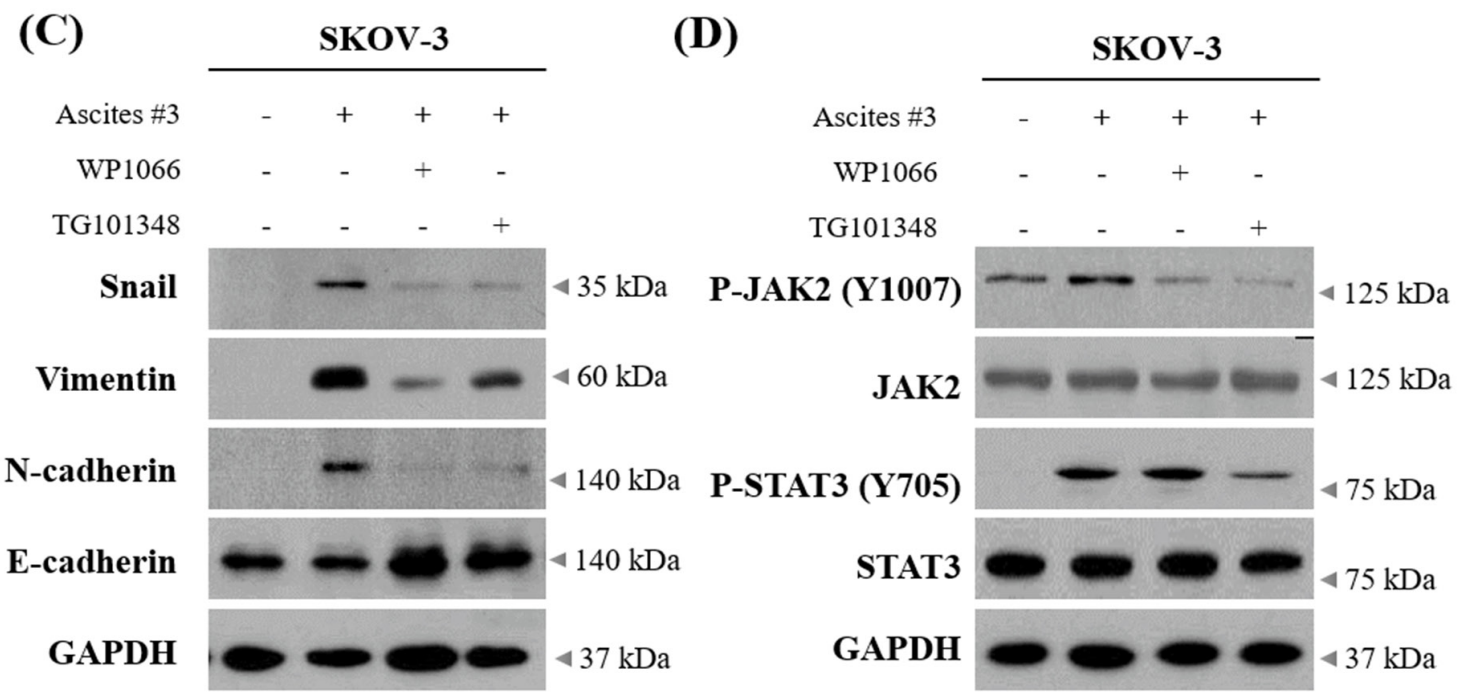

Figure 4: Inhibition of JAK2-STAT3 signaling suppress ascites-induced migration and invasion in SKOV-3 cells. A. SKOV-3 cancer cells were treated with 10\% ascites, with or without JAK2 and STAT3 inhibitors, WP1066 and TG101348. After 24 hr, wound healing ability was verified by measuring wound closed area under a light microscope (magnification x40). B. SKOV-3 cancer cells were seeded into the upper chamber of Matrigel-coated membrane in transwells. Cell invasion were induced by ascites with or without JAK2 and STAT3 inhibitors. After $24 \mathrm{hr}$, invaded cells at the bottom of the transwell were stained with $0.5 \%$ crystal violet and counted under a light microscope (magnification x200). C. SKOV-3 cancer cells were treated with JAK2 and STAT3 inhibitors as above. After 24 $\mathrm{hr}$, the expression of Snail, Vimentin, N-cadherin and E-cadherin were examined by western blot. GAPDH was used as an internal control. D. SKOV-3 cancer cells were treated as above. The expression of p-JAK2 (Y1007), JAK2, p-STAT3 (Y705) and STAT3 were examined by western blot. GAPDH was used as an internal control. ** and *** represent $P<0.01$ and $P<0.001$, respectively. 


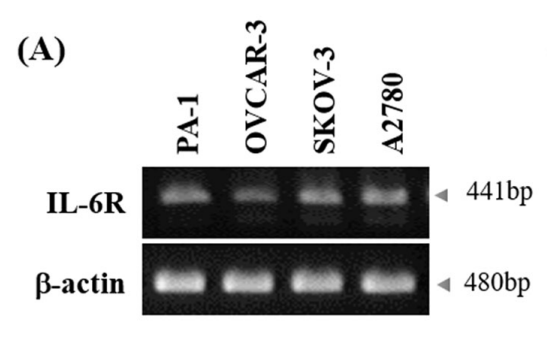

(C)

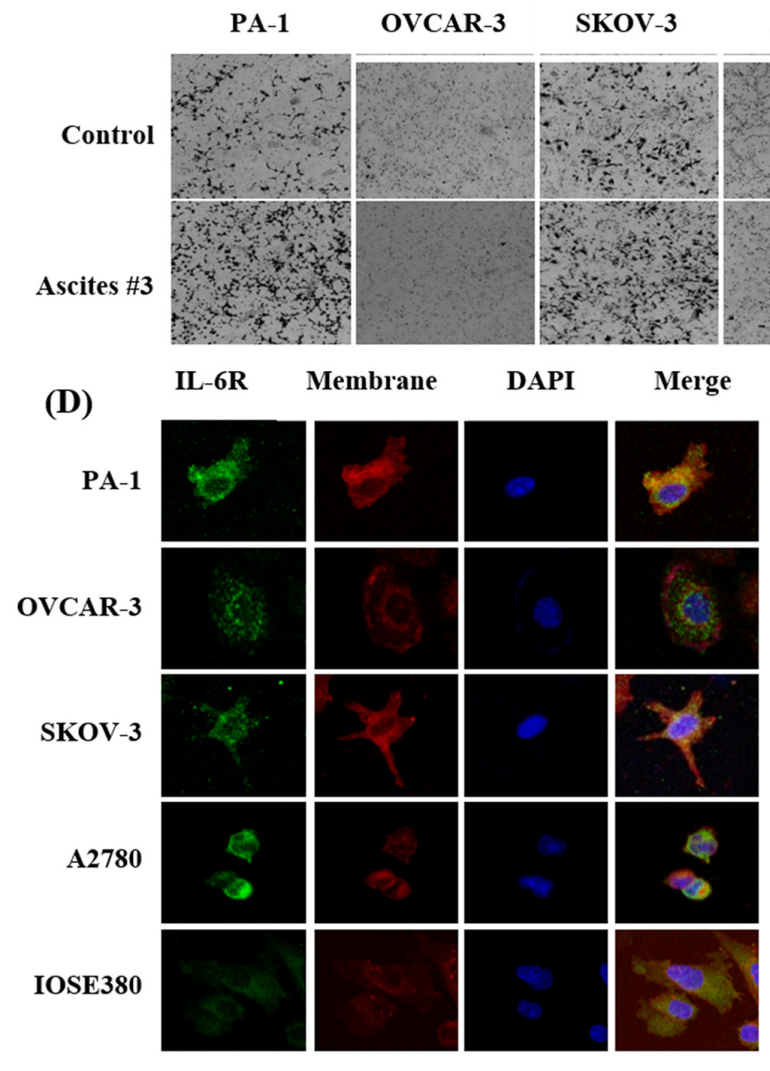

(E)

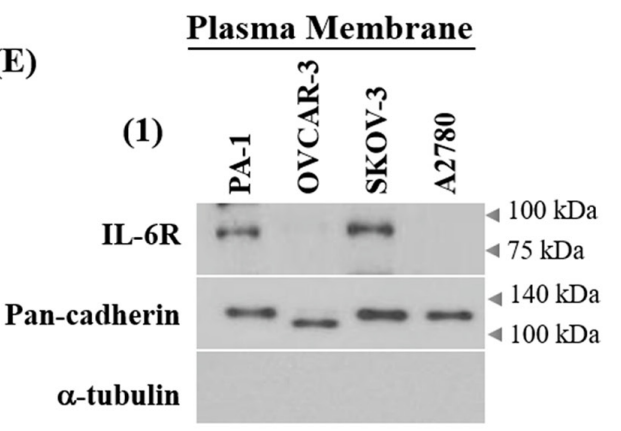

(B)

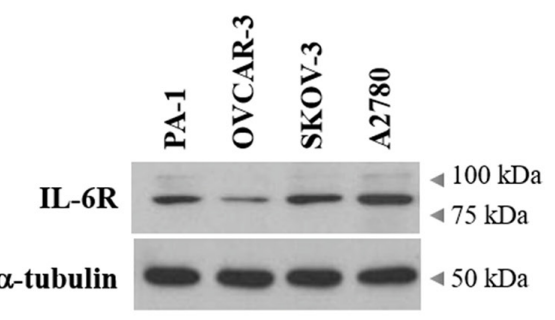


levels above $3 \mathrm{ng} / \mathrm{ml}$ in ascites is associated with poor prognosis in patients with ovarian cancer [10]. In line with this previous report, ascites collected in our study setting had higher IL-6 levels compared to reports by Lane et al. (Supplementary Figure S2C). Interestingly, early studies suggest that ascites in ovarian cancer patients forms a protective TME against drug-induced apoptosis by inducing survival signaling pathways such as PI3K/ Akt $[26,27]$. Moreover, the extent to which ascites served as protective TME was dependent on patients [9], which highlights inter-patient variability in the components of ascites. Similarly, although all three ascites tested in study increased invasion, we also observed that the magnitude of increased migration and invasion by ascites were variable among the patients (Figure 1A and 1B).

The metastasis is a critical step in determining the outcome of ovarian cancer patients, therefore preventing metastasis would improve prognosis in ovarian cancer patients [28]. Although a number of biological molecules related to metastasis in ovarian tumors have been elucidated [29], the precise role of IL-6R expression on cell membrane is undefined. Accumulating evidence suggests a rationale for anti- IL-6/IL-6R therapy for ovarian cancer treatment [30-32]. The inhibition of IL-6R using tocilizumab almost completely inhibited invasion promoted by the microenvironment [30]. Similarly, neutralization of IL-6 significantly enhanced the therapeutic efficacy of paclitaxel in mouse models of EOC by reducing tumor growth [33].

Our results demonstrate that IL-6R protein expression on plasma membrane of PA-1 and SKOV-3 cancer cells but not in cytosol predicts responsiveness to ascites in cell-based models of EOC invasion (Figure 5E12 ). Further study across a broader spectrum of patientderived ascites and tumor samples is needed to fully investigate this hypothesis.

(A)

\section{PA-1 SKOV-3}

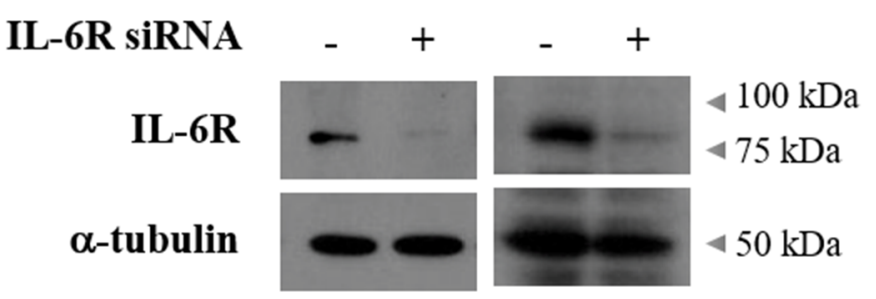

(B) PA-1 SKOV-3

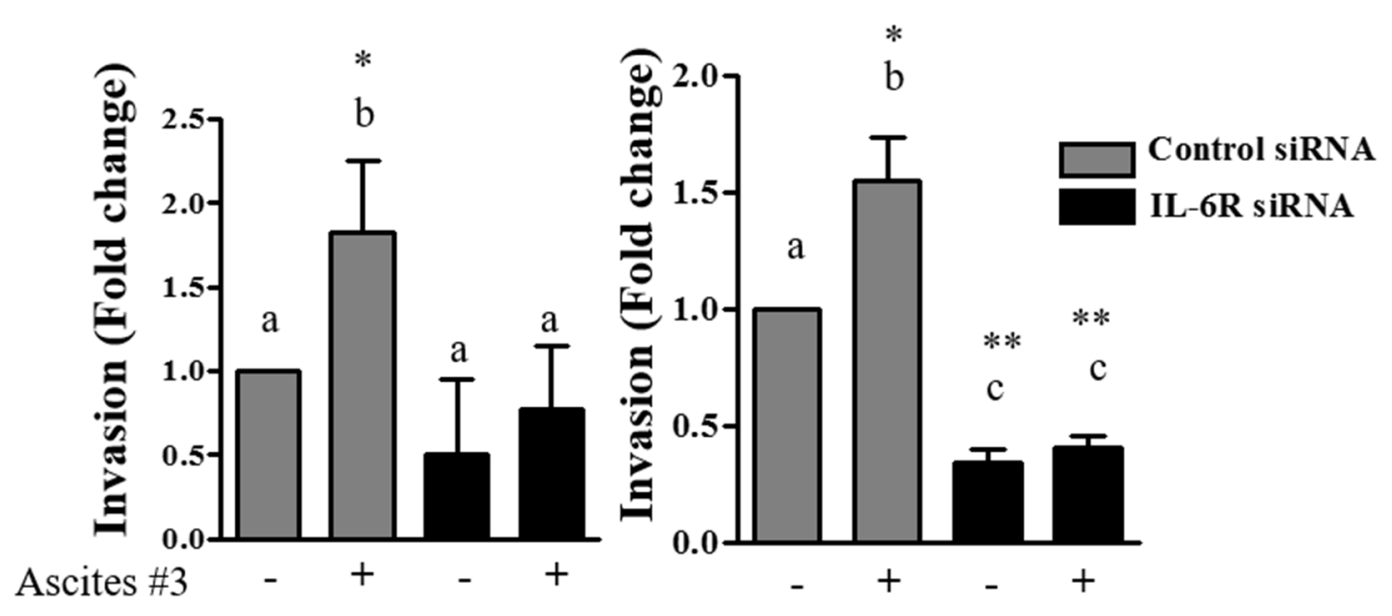

Figure 6: Silencing of IL-6R impairs ascites-induced invasion. A. PA-1 and SKOV-3 cells were transfected with IL-6R targeted siRNA $(100 \mathrm{nM})$ or scrambled RNA $(100 \mathrm{nM})$ as a negative control. Silencing of IL-6R expression was examined by western blot. B. PA-1 and SKOV-3 cells were transfected with IL-6R targeted siRNA $(100 \mathrm{nM})$ or negative control scrambled RNA (100 nM) for $24 \mathrm{hr}$. Cells were seeded into the upper chamber of Matrigel-coated membrane in transwells. Cell invasion were induced by $10 \%$ ascites. After 24, invaded cells at the bottom of the transwell were stained with $0.5 \%$ crystal violet and were counted under a light microscope (magnification $\mathrm{x} 200$ ). The data summarized in the bar charts are presented as mean $\pm \mathrm{SD}$ of three independent fields. * and ** represent $P<0.05$ and $P<0.01$, respectively. 
Collectively, the findings presented herein demonstrate that IL-6 in ascites function through membrane-bound IL-6R expressed in cancer cells and increase the EOC cell invasion via JAK2-STAT3 signaling. Targeting IL-6, IL-6R or JAK2/STAT3 may offer an efficient management of ascites induced migration and invasion in ovarian cancer patients.

\section{MATERIALS AND METHODS}

\section{Cell culture, clinical samples and reagents}

Human ovarian cancer cell lines, PA-1, OVCAR-3, and SKOV-3 used in this study were obtained from the American Type Culture Collection (Rockville, MD). A2780 was kindly gifted by Prof. Benjamin K. Tsang. With the exception of PA-1, these cell lines were grown in RPMI1640 (WelGENE, Seoul, Korea). PA-1 was cultured in MEM (WelGENE, Seoul Korea).

Induced ovarian surface epithelial cell line IOSE380 used in this study was kindly gifted by Prof. Young Kee Shin. The IOSE380 cell line was maintained in MCDB105:M199, 1:1 mixture. All culture media were supplemented with 10\% FBS (Gibco-BRL, Gaithersberg, $\mathrm{MD})$, and $100 \mu \mathrm{g} / \mathrm{mL}$ penicillin-streptomycin $(\mathrm{P} / \mathrm{S})$ (Invitrogen, Carlsbard, CA).

Ascites from three serous ovarian cancer patients and peritoneal fluid from two benign conditions were collected at the time of clinical intervention at the Seoul National University Hospital (Seoul, Korea). This study was approved by the Institutional Review Board (IRB) at Seoul national University Hospital (Registration number: 1409-1540-616), and prior written and informed consent was obtained from every patient. Ascites were centrifuged at $2500 \mathrm{rpm}$ for 20 minutes. The acellular fractions were filtered $(70 \mu \mathrm{m})$, aliquoted and stored at $-80^{\circ} \mathrm{C}$ to minimize freeze-thaw.

\section{Wound healing assay}

Cells were full plated with complete media in 6-well plates and incubated at $37^{\circ} \mathrm{C}$ for $24 \mathrm{hr}$. The complete medium was changed to either fresh complete media or $10 \%$ of the indicated ascites. The cell layer was scratched with a pipette tip to create an artificial wound. The wound closed area (in arbitrary unit) was measured using ImageJ software.

\section{Invasion assay}

To assess the influence of ascites on the invasion, the Boyden chamber assay (transparent PET membrane with 8 $\mu \mathrm{m}$ pore size, BD Biosciences) was used. Inserts were precoated with growth factor reduced Matrigel (30 $\mu \mathrm{g} / \mathrm{insert}$; $\mathrm{BD}$ Biosciences). Cells were serum starved overnight and 40,000 cells were loaded to the upper chamber per insert and the inserts were placed to $10 \%$ of the indicated ascites or control medium. After $24 \mathrm{hr}$, cells were washed with
PBS for three times and fixed with $4 \%$ formaldehyde for $1 \mathrm{hr}$ at room temperature and stained with $0.5 \%$ crystal violet. Non-invaded cells were removed from the top filter surface with a cotton swab and invaded cells were viewed and photographed under a microscope. The invaded cells were counted using ImageJ software.

\section{Western blotting}

Protein lysates were prepared as described previously [34]. In brief, after cell extraction, proteins were separated by SDS/PAGE (6-15\% gel, depending on specific protein assessed) followed by electrotransfer onto nitrocellulose membranes and probed with the indicated antibodies.

\section{Reagents and antibodies}

WP1066 and TG101348 (Selleckchem) were used in this study. Anti-recombinant human interleukin-6 (antirh IL-6), rh interleukin-6 (rh IL-6) and normal goat IgG were purchased from R\&D Systems (R\&D Systems, MN). JAK2, pJAK2 (Y1007), STAT3, pSTAT3 (Y705) and $\mathrm{N}$-cadherin were purchased from Cell signaling (Danvers, MA). Snail, E-cadherin, Vimentin, GAPDH and IL-6R were purchased from Santa Cruz Biotechnology (Santa Cruz, CA). $\alpha$-tubulin antibody was obtained from SigmaAldrich. Alexa Fluor conjugated anti-rabbit antibody was obtained from Invitrogen (Carlsbad, CA).

\section{Ascites analysis using proteome profiler cytokine array}

Measured by the Human Cytokine Array Kit (R\&D Systems), according to the manufacturing protocols. Ascites from two ovarian cancer patients and peritoneal fluid from two benign conditions were subjected to human cytokine array to detect the relative expression levels of 36 different cytokines.

\section{Determination of IL-6 concentration by ELISA}

IL-6 levels in ascites samples were determined by ELISA using the commercially available human Quantikine HS ELISA Kit (R\&D Systems, MN). The assays were performed in duplicate according to the manufacturer's protocols. The detection threshold was $0.156 \mathrm{pg} / \mathrm{ml}$. A quantity of $50 \mu \mathrm{l}$ of undiluted ascites was added in each well.

\section{Depletion of soluble interleukin-6}

$10 \%$ ascites diluted in complete medium were incubated with $50 \mathrm{ng} / \mathrm{ml}$ of a goat polyclonal anti-rh interleukin-6 (anti-rh IL-6; R\&D Systems, MN) or a normal goat IgG control (R\&D Systems, MN) at $37^{\circ} \mathrm{C}$ for $6 \mathrm{hr}$. The media were used in invasion assay as described above. 


\section{RT-PCR}

Total RNA was extracted with Trizol reagent (Life Technologies, Gaithersburg, MD). Single-stranded cDNA was constructed by PrimeScript Reverse Transcriptase (Takara, Japan). PCR was performed with specific primers IL-6R sense 5'-TCC ACC CCC ATG CAG GCA CT-3', antisense 5'-GTGCCACCCAGCCAGCTATC-3' (size, 441 bp); IL-6 sense 5'-TAG CCG CCC CAC ACA GAC AG-3', antisense 5'-GGC TGG CAT TTG TGG TTG GG-3' (size, 408 bp); and $\beta$-actin sense 5'-ACA CTG CCA TCT ACG AGC-3', antisense 5'-AGG GGC CGG ACT CGT CAT ACT-3' (size, $480 \mathrm{bp}$ ) using the following amplification conditions: denaturation $\left(95^{\circ} \mathrm{C}\right.$, $30 \mathrm{~s})$, annealing $\left(60^{\circ} \mathrm{C}, 30 \mathrm{~s}\right)$, and extension $\left(72^{\circ} \mathrm{C}, 1 \mathrm{~min}\right)$ followed by 35 cycles $\left(72^{\circ} \mathrm{C}, 10 \mathrm{~min}\right)$.

\section{Small interfering RNA transfection}

The siRNA-targeting IL-6R (100 nM) gene corresponds to sequence was CGA CUC UGG AAA CUA UUC ATT and scrambled RNA (100 nM) was used as a negative control (mBioTech, Gyeonggido, Korea). All cancer cells were transfected with siRNA oligonucleotides with Lipofectamine ${ }^{\circledR} 2000$ (Life Technologies). At $24 \mathrm{hr}$ post-transfection cells were harvested and subsequently used for invasion assay.

\section{Immunofluorescence microscopy}

Cells were plated onto a cover-slip and grown overnight in normal cell culture condition. The cells were fixed with $4 \%$ formaldehyde and blocked with $5 \%$ of goat serum. The anti-IL-6R antibody (1:500), Alexa Fluor conjugated anti-rabbit antibody (1:1000) and the membrane specific dye (CellMask ${ }^{\mathrm{TM}}$ Deep Red Plasma Membrane Stain, Invitrogen) were used for IL6R membrane localization. Imaging was performed using a Confocal-A1 imaging system (Nikon). Original magnification was 400x for all panels, respectively.

\section{Statistical analysis}

Data were presented as mean $\pm \mathrm{SD}$ of triplicate experiments. One-way ANOVA and, when appropriate, Student's t-test were used for statistical analyses. Significant difference among experimental groups was analyzed by Scheffe's post hoc test. All analyses were conducted using IBM SPSS statistics 21 (SPSS Inc., Chicago, IL). P values of $<0.05$ were considered statistically significant.

\section{ACKNOWLEDGMENTS}

Human ovarian cancer cell line A2780 was kindly gifted by Prof. Benjamin K. Tsang in University of Ottawa (Ottawa, Canada). For normal induced ovarian surface epithelial cell line, IOSE380 was kindly gifted by Prof. Young Kee Shin in Seoul National University (Seoul, Korea). For patient derived ascites and peritoneal fluid, we followed the IRB approved protocol (14091540-616).

\section{CONFLICTS OF INTEREST}

The authors have no conflicts of interest.

\section{GRANT SUPPORT}

This research was supported by the Priority Research Centers Program (2009-0093820), BK21 plus program (5262-20150100) through the National Research Foundation of Korea (NRF) funded by the Ministry of Education and grants from Seoul National University College of Medicine (800-20150304) and the National Institutes of Health (CA116984).

\section{REFERENCES}

1. Narod S. Can advanced-stage ovarian cancer be cured? Nat Rev Clin Oncol. 2016; 13:255-261.

2. Tan DS, Agarwal R and Kaye SB. Mechanisms of transcoelomic metastasis in ovarian cancer. Lancet Oncol. 2006; 7:925-934.

3. Parsons SL, Lang MW and Steele RJ. Malignant ascites: a 2-year review from a teaching hospital. Eur J Surg Oncol. 1996; 22:237-239.

4. Ayantunde AA and Parsons SL. Pattern and prognostic factors in patients with malignant ascites: a retrospective study. Ann Oncol. 2007; 18:945-949.

5. Puiffe ML, Le Page C, Filali-Mouhim A, Zietarska M, Ouellet V, Tonin PN, Chevrette M, Provencher DM and Mes-Masson AM. Characterization of ovarian cancer ascites on cell invasion, proliferation, spheroid formation, and gene expression in an in vitro model of epithelial ovarian cancer. Neoplasia. 2007; 9:820-829.

6. Goncharenko-Khaider N, Matte I, Lane D, Rancourt C and Piche A. Ovarian cancer ascites increase Mcl-1 expression in tumor cells through ERK1/2-Elk-1 signaling to attenuate TRAIL-induced apoptosis. Mol Cancer. 2012; 11:84.

7. Carduner L, Leroy-Dudal J, Picot CR, Gallet O, Carreiras F and Kellouche S. Ascites-induced shift along epithelial-mesenchymal spectrum in ovarian cancer cells: enhancement of their invasive behavior partly dependant on alphav integrins. Clin Exp Metastasis. 2014; 31:675-688.

8. Kim S, Kim B and Song YS. Ascites modulates cancer cell behavior, contributing to tumor heterogeneity in ovarian cancer. Cancer Sci. 2016.

9. Lane D, Matte I, Rancourt C and Piche A. The prosurvival activity of ascites against TRAIL is associated with a shorter disease-free interval in patients with ovarian cancer. J Ovarian Res. 2010; 3:1. 
10. Lane D, Matte I, Rancourt C and Piche A. Prognostic significance of IL-6 and IL-8 ascites levels in ovarian cancer patients. BMC Cancer. 2011; 11:210.

11. Lane D, Matte I, Garde-Granger P, Laplante C, Carignan A, Rancourt $\mathrm{C}$ and Piche A. Inflammation-regulating factors in ascites as predictive biomarkers of drug resistance and progression-free survival in serous epithelial ovarian cancers. BMC Cancer. 2015; 15:492.

12. Kumar $\mathrm{J}$ and Ward AC. Role of the interleukin 6 receptor family in epithelial ovarian cancer and its clinical implications. Biochim Biophys Acta. 2014; 1845:117-125.

13. Ho CM, Chang SF, Hsiao CC, Chien TY and Shih DT. Isolation and characterization of stromal progenitor cells from ascites of patients with epithelial ovarian adenocarcinoma. J Biomed Sci. 2012; 19:23.

14. Vergara D, Merlot B, Lucot JP, Collinet P, Vinatier D, Fournier I and Salzet M. Epithelial-mesenchymal transition in ovarian cancer. Cancer Lett. 2010; 291:59-66.

15. De Craene B and Berx G. Regulatory networks defining EMT during cancer initiation and progression. Nature reviews Cancer. 2013; 13:97-110.

16. Matte I, Lane D, Laplante C, Garde-Granger P, Rancourt C and Piche A. Ovarian cancer ascites enhance the migration of patient-derived peritoneal mesothelial cells via cMet pathway through HGF-dependent and -independent mechanisms. Int J Cancer. 2014.

17. Cohen $\mathrm{M}$ and Petignat $\mathrm{P}$. The bright side of ascites in ovarian cancer. Cell Cycle. 2014; 13:2319.

18. Malek JA, Mery E, Mahmoud YA, Al-Azwani EK, Roger L, Huang R, Jouve E, Lis R, Thiery JP, Querleu D and Rafii A. Copy number variation analysis of matched ovarian primary tumors and peritoneal metastasis. PloS one. 2011; 6:e28561.

19. Teng Y, Ross JL and Cowell JK. The involvement of JAKSTAT3 in cell motility, invasion, and metastasis. JAKSTAT. 2014; 3:e28086.

20. Ahmed N and Stenvers KL. Getting to know ovarian cancer ascites: opportunities for targeted therapy-based translational research. Front Oncol. 2013; 3:256.

21. Matte I, Lane D, Laplante C, Rancourt C and Piche A. Profiling of cytokines in human epithelial ovarian cancer ascites. Am J Cancer Res. 2012; 2:566-580.

22. Giuntoli RL, 2nd, Webb TJ, Zoso A, Rogers O, Diaz-Montes TP, Bristow RE and Oelke M. Ovarian cancer-associated ascites demonstrates altered immune environment: implications for antitumor immunity. Anticancer Res. 2009; 29:2875-2884.

23. Yigit R, Figdor CG, Zusterzeel PL, Pots JM, Torensma R and Massuger LF. Cytokine analysis as a tool to understand tumour-host interaction in ovarian cancer. Eur J Cancer. $2011 ; 47: 1883-1889$.
24. Lutticken C, Wegenka UM, Yuan J, Buschmann J, Schindler C, Ziemiecki A, Harpur AG, Wilks AF, Yasukawa K, Taga $\mathrm{T}$ and et al. Association of transcription factor APRF and protein kinase Jak1 with the interleukin-6 signal transducer gp130. Science. 1994; 263:89-92.

25. Zhong Z, Wen Z and Darnell JE, Jr. Stat3: a STAT family member activated by tyrosine phosphorylation in response to epidermal growth factor and interleukin-6. Science. 1994; 264:95-98.

26. Lane D, Robert V, Grondin R, Rancourt C and Piche A. Malignant ascites protect against TRAIL-induced apoptosis by activating the PI3K/Akt pathway in human ovarian carcinoma cells. Int J Cancer. 2007; 121:1227-1237.

27. Lane D, Goncharenko-Khaider N, Rancourt C and Piche A. Ovarian cancer ascites protects from TRAIL-induced cell death through alphavbeta5 integrin-mediated focal adhesion kinase and Akt activation. Oncogene. 2010; 29:3519-3531.

28. Li J, Zhou J, Chen G, Wang H, Wang S, Xing H, Gao Q, Lu $\mathrm{Y}, \mathrm{He} \mathrm{Y}$ and Ma D. Inhibition of ovarian cancer metastasis by adeno-associated virus-mediated gene transfer of $\mathrm{nm} 23 \mathrm{H} 1$ in an orthotopic implantation model. Cancer Gene Ther. 2006; 13:266-272.

29. Zhao H, Jhanwar-Uniyal M, Datta PK, Yemul S, Ho L, Khitrov G, Kupershmidt I, Pasinetti GM, Ray T, Athwal RS and Achary MP. Expression profile of genes associated with antimetastatic gene: nm23-mediated metastasis inhibition in breast carcinoma cells. Int J Cancer. 2004; 109:65-70.

30. Isobe A, Sawada K, Kinose Y, Ohyagi-Hara C, Nakatsuka E, Makino H, Ogura T, Mizuno T, Suzuki N, Morii E, Nakamura K, Sawada I, Toda A, et al. Interleukin 6 receptor is an independent prognostic factor and a potential therapeutic target of ovarian cancer. PloS one. 2015; 10:e0118080.

31. Colomiere M, Ward AC, Riley C, Trenerry MK, CameronSmith D, Findlay J, Ackland L and Ahmed N. Cross talk of signals between EGFR and IL-6R through JAK2/STAT3 mediate epithelial-mesenchymal transition in ovarian carcinomas. Br J Cancer. 2009; 100:134-144.

32. Guo Y, Xu F, Lu T, Duan Z and Zhang Z. Interleukin-6 signaling pathway in targeted therapy for cancer. Cancer Treat Rev. 2012; 38:904-910.

33. Coward J, Kulbe H, Chakravarty P, Leader D, Vassileva V, Leinster DA, Thompson R, Schioppa T, Nemeth J, Vermeulen J, Singh N, Avril N, Cummings J, et al. Interleukin- 6 as a therapeutic target in human ovarian cancer. Clin Cancer Res. 2011; 17:6083-6096.

34. Kim SH, Kim SH, Kim YB, Jeon YT, Lee SC and Song YS. Genistein inhibits cell growth by modulating various mitogen-activated protein kinases and AKT in cervical cancer cells. Annals of the New York Academy of Sciences. 2009; 1171:495-500. 